Michuda Yu, Mustafa Ismail. Conditions of forming organizational bases for marketing usage in football of Lebanon. Theory and Methods of Physical education and sports. 2019; 1: 21-24 DOI:10.32652/ tmfvs.2019.1.21-24
Мічуда Ю, Мустафра Ісмаїл. Умови формування організаційних основ застосування маркетингу в фрутболі Лівану. Теорія і методика фізичного виховання і спорту. 2019; 1: 21-24 DOI:10.32652/tmfvs.2019.1.21-24

\title{
УМОВИ ФОРМУВАННЯ ОРГАНІЗАЦИЙНИХ ОСНОВ ЗАСТОСУВАННЯ МАРКЕТИНГУ В ФУТБОЛІ ЛІВАНУ
}

\section{Юрій Мічуда, Мустафа Ісмаїл}

\author{
Національний університет фізичного виховання і спорту України, Київ, Україна
}

\begin{abstract}
Анотація. Розглянуто умови та шляхи формування маркетингової політики у футбболі Лівану. Мета. Визначити умови формування організаційних основ застосування маркетингу в ффутболі Лівану. Методи. Аналіз спеціальної літератури та документальних джерел, системний аналіз управлінської діяльності в футболі. Результати. Використано результати соціологічного анкетування фрахівців з питань застосування маркетингу футбольними організаціями Лівану. В дослідженні взяли участь 202 респонденти (керівники, фрахівці Федерації фрутболу Лівану та фрутбольних клубів Прем'єр-ліги). Встановлено, що перебіг процесу застосування маркетингу в управлінні футтбольними організаціями Лівану обумовлюється впливом сукупності фракторів, які залежать від характеру макро- та мікросередовища. Здійснено аналіз фракторів, які впливають на створення організаційних основ впровадження маркетингу в управлінську діяльність ліванських футтбольних клубів, що належать до вищого ешелону ліванського футболу - Прем'єр-ліги - і посідають провідні місця на національному ринку спортивно-видовищних послуг. Визначено та охарактеризовано фрактори, які перешкоджають футбольним клубам формувати та реалізувати ефрективну маркетингову політику.
\end{abstract}

Ключові слова: фрутбол, організаційні основи, маркетинг, управління маркетингом, програма маркетингу.

\section{Yuriy Michuda, Mustafa Ismail \\ CONDITIONS OF FORMING ORGANIZATIONAL BASES FOR MARKETING USAGE IN FOOTBALL OF LEBANON}

\begin{abstract}
The conditions and ways of forming a marketing policy in football of Lebanon are considered. Objective. To determine the conditions for the formation of the organizational framework for football marketing in Lebanon. Methods. Analysis of special literature and documentary sources, system analysis of management activities in football. Results. The results of sociological survey of specialists on usage of marketing by football organizations of Lebanon have been used. The study included 202 respondents (leaders, specialists of the Football Federation of Lebanon and football clubs of the Premier League). It has been established that the process of applying marketing in the management of football organizations in Lebanon is determined by the influence of a set of factors that depend on the nature of the macro and micro environment. The factors influencing the creation of the organizational bases for marketing introduction in managing activity of the Lebanese football clubs that belong to the highest level of the Lebanese football - the Premier League - and occupy the leading places at the national market of sports and entertainment services have been analyzed. The factors that prevent football clubs from forming and implementing an effective marketing policy have been identified and described.
\end{abstract}

Keywords: football, organizational bases, marketing, marketing management, marketing program.

Вступ. Сучасний етап розвитку ліванського футболу висуває перед його керівними органами та спортивною громадськістю важливі завдання. Головним серед них є визначення стратегічного шляху його подальшого розвитку, що має спиратись на сучасні тенденції у світовому футболі. Однією з них є активне застосування футбольними організаціями маркетингу як ефективної складової спортивного менеджменту. Сьогодні маркетинг застосовують у футболі на різних рівнях його організації. Передовсім це стосується національних систем управління видом спорту. Досвід багатьох країн переконливо свідчить, що впровадження методів маркетингу є важливою умовою розвитку національного футболу, насамперед його професійного компонента [2, 3, 7].

Ця обставина є вельми актуальною для ліванського футболу, який за своїм статусом продо- вжує бути переважно аматорським, що не дозволяє йому вирішувати завдання на національному та міжнародному рівнях, адекватні його популярності серед населення країни. Застосування маркетингу може дозволити футбольним організаціям вирішувати ряд життево важливих для них питань: задовольняти постійно зростаючі потреби у фінансових та матеріальних ресурсах, залучати висококваліфікованих гравців, активізувати відвідування матчів глядачами, налагоджувати сталі зв'язки із засобами масової інформації тощо. Це, у свою чергу, обумовлює важливість наукових досліджень, які мають визначити умови, за яких можуть бути створені організаційні основи використання маркетингу у футболі Лівану.

Дослідження проведено в рамках теми 1.10 «Теоретичні та прикладні аспекти підприємни- 


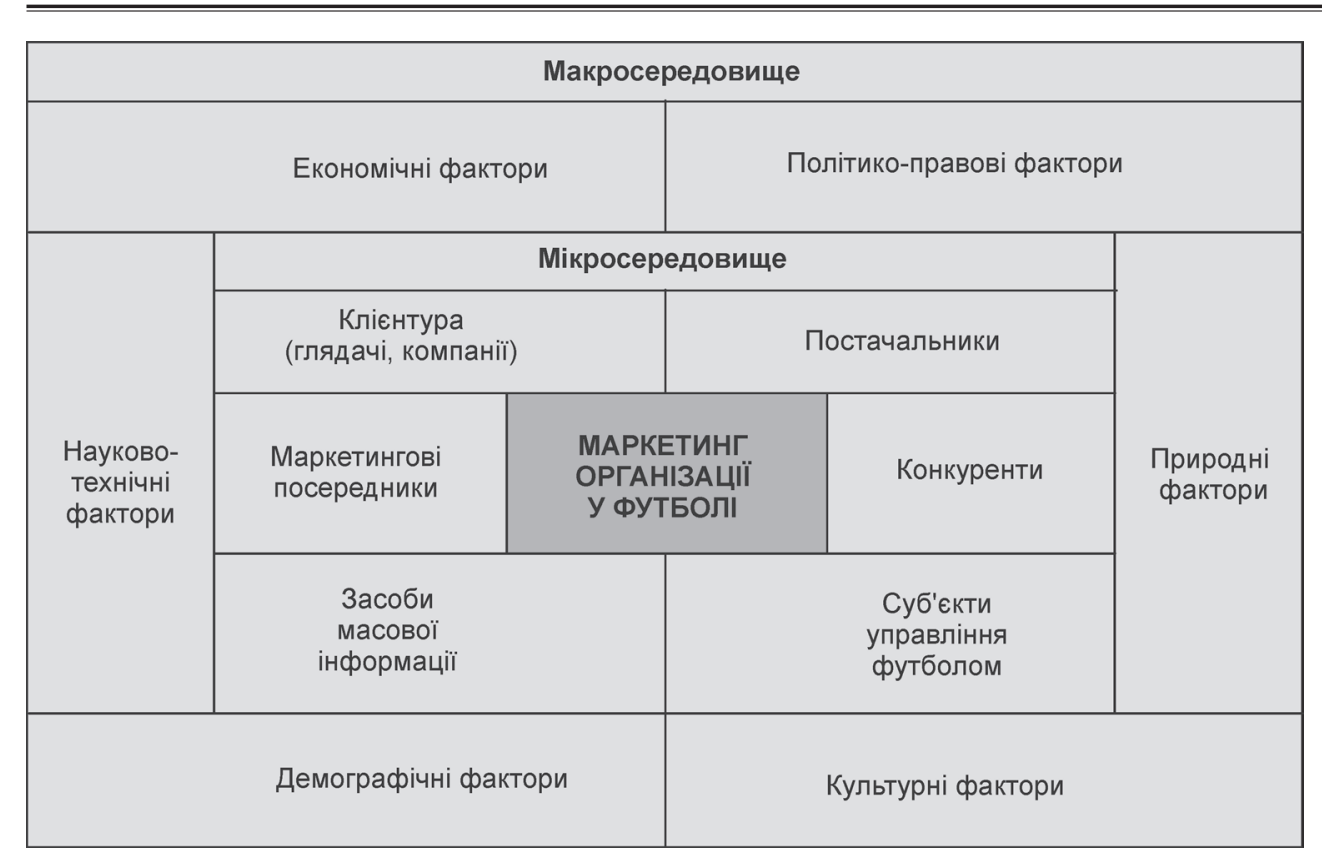

Рисунок 1 - Маркетингове середовище організації у футболі цтва у сучасному спорті» Зведеного плану НДР Національного університету фізичного виховання і спорту України на 2016-2020 рр. (номер держреєстрації 0116U001622).

Мета дослідження - визначити умови формування організаційних основ застосування маркетингу у футболі Лівану.

Методи дослідження: соціологічне анкетування фахівців із питань застосування маркетингу футбольними організаціями Лівану; аналіз спеціальної літератури та документальних джерел, системний аналіз управлінської діяльності.

Результати дослідження та їх обговорення. У дослідженні взяли участь 202 респонденти: керівники, фахівці, стейкхолдери Федерації футболу Лівану - 105 осіб та футбольних клубів Прем'єрліги - 97 осіб. Аналізуючи можливості застосування маркетингу в управлінні футбольними організаціями Лівану, варто взяти до уваги ту обставину, що перебіг цього процесу обумовлюється впливом сукупності факторів, які залежать від характеру зовнішнього середовища. У теорії маркетингу цей феномен має назву маркетингове середовище, під яким розуміють сукупність зовнішніх факторів i сил, що впливають на здатність організації підтримувати й розвивати успішні торговельні операції клієнтами своїх цільових ринків [6].

Це поняття дослідники розглядають як таке, що може бути застосоване й у сфері футболу, насамперед іiї професійної складової. «В управлінні елітною футбольною командою, - зазначають Д. Болховер і К. Бреді, - відбито всі проблеми корпоративного управління в глобальному середовищі». На їхню думку, проблеми, 3 якими стикаються сучасні організації, абсолютно аналогічні тим, що постають перед футбольними командами. Вони містять суперечки про розподіл обов'язків між вищими корпоративними керівниками й голо- вами правлінь, так звану «війну талантів», розробку стратегічного напряму, створення тактичних планів, зміну й наступність менеджерів, взаємини між керівниками вищої ланки й головами рад директорів, акціонерами, засобами масової інформації й органами державного регулювання. Усе це - взаємини, що є ключовими як для бізнесу, так і для футболу [1].

Маркетингове середовище спортивної організації у футболі об'єднує мікросередовище та макросередовище (рис. 1). Мікросередовище представлене силами, що безпосередньо стосуються самого клубу і його можливостей 3 обслуговування клієнтури, тобто постачальниками, маркетинговими посередниками, глядачами, конкурентами й контактними аудиторіями. Макросередовище представлене силами широкого спектра соціального плану, які впливають на мікросередовище факторами демографічного, економічного, технічного, політичного, культурного характеру [5].

Головним компонентом мікросередовища виступає сама футбольна організація як різновид фірми (федерація футболу, ліга, футбольний клуб) і як виробник спортивно-видовищних послуг (ліга, футбольний клуб). Виходячи 3 особливостей предмета дослідження, нас цікавлять насамперед футбольні клуби, які є реальними учасниками національного ринку спортивно-видовищних послуг, тобто ті, що належать до вищого ешелону ліванського футболу - Прем'єр-ліги. На сьогодні вона об'єднує дванадцять найсильніших клубів країни (сезон 2017-2018 рр.).

Аналіз складу Прем'єр-ліги свідчить, що вищий футбольний ешелон Лівану сформований таким чином, що у ньому виникають об'єктивні складнощі в організації маркетингової діяльності клубів та самої ліги. Насамперед варто звернути увагу на нераціональне формування національного рин- 
ку спортивно-видовищних послуг, що обумовлено нерівномірним розташуванням по країні футбольних клубів. Близько половини їх - п'ять - дислокуються в столиці країни Бейруті, де проживає 1,5 млн осіб з 4,2 млн населення країни $(35,7$ \%) [4]. Решта сім клубів розташовані в інших регіонах країни. Така географія разом з напруженою політичною ситуацією навколо країни створює об'єктивні перепони у реалізації програм залучення глядачів. До того ж, більшість клубів не мають власних стадіонів, які відповідають сучасним міжнародним стандартам, що не лише ускладнює роботу з глядачами, а й не дозволяє реалізувати інші маркетингові програми.

Головне завдання маркетингу футбольного клубу - забезпечити виробництво товару (спортивновидовищної послуги), привабливого з погляду цільових ринків. Як і в інших країнах, у Лівані діють два цільових ринки спортивно-видовищних послуг. Суб'єктами першого є глядачі («первинні» споживачі послуг). Другий ринок представляють комерційні компанії та засоби масової інформації («вторинні» споживачі послуг).

Слід взяти до уваги, що на сьогодні аналіз реальної ситуації, котра склалась на вказаних ринках, значно ускладнений рядом обставин. Справа в тому, що протягом багатьох років ні Прем'єр-ліга, ні Федерація футболу Лівану не здійснюють систематичного аналізу стану відвідуваності глядачами ігор клубів. Це не дозволяє керівникам та фахівцям визначати стратегію і тактику роботи із залучення глядачів на стадіони, що є важливою умовою ефективної маркетингової діяльності. У peзультаті середня кількість глядачів на матчах клубів Прем'єр-ліги не перевищує 5-6 тис. чоловік.

Дефіцит глядачів став фактором мікросередовища, що на сьогодні істотно перешкоджає формуванню ефективної маркетингової політики футбольних клубів Лівану. Дія цього фактора також позначилася на другому цільовому ринку послуг, що представлений комерційними компаніями. Слід зазначити, що компанії як компоненти мікросередовища маркетингу футбольних клубів Лівану здатні виконати ряд важливих функцій. По-перше, виступаючи в ролі спонсорів, рекламодавців або ліцензіатів, вони можуть сприяти популяризації футбольних клубів серед тієї частини населення, котра є покупцем їхніх товарів. Тим самим створюватимуть умови для розширення першого 3 розглянутих ринків послуг професійного футболу в країні. По-друге, компанії можуть виступати як інвестори футбольних клубів, що забезпечують їх фінансовими або матеріальними ресурсами (спортивною формою, м'ячами, екіпіруванням, устаткуванням тощо), необхідними для виробництва якісних послуг.

Важливо взяти до уваги, що у вельми несприятливих ринкових умовах футбольні організації Лівану, насамперед клуби, стикаються з безліччю проблем, пов’язаних з організацією маркетингової діяльності. Керівництву й фахівцям клубів у біль- шості випадків бракує знань та навичок ефективного вирішення таких проблем. У цьому їм могли б надати допомогу спеціалізовані компанії - маркетингові посередники. Проведене нами опитування засвідчило, що лише кожен шостий клуб практикує співробітництво з маркетинговими або рекламними агентствами.

Такий стан речей об'єктивно обумовлений. У багатьох клубах, насамперед тих, що належать до муніципальної власності, 3 минулих часів збереглася система управління, побудована на директивних принципах і яка не передбачає систематичного аналізу ринкового середовища, а отже, і відповідного аналізу використання маркетингу. Ті клуби, які розглядали й розглядають себе як більш-менш активних суб'єктів ринку, сьогодні стикаються зі значними фінансовими проблемами i не можуть передбачити у своїх бюджетах необхідні кошти для укладання угод з маркетинговими посередниками. Крім того, у зв'язку із загальною стагнацією економіки Лівану, значно скоротилася пропозиція на ринку маркетингових послуг, що ускладнює доступ до них футбольних клубів.

Не кращою є ситуація й 3 іншими партнерамипосередниками футбольних клубів Лівану - медіакомпаніями. Йдеться передовсім про телевізійні компанії, співробітництво з якими дає можливість клубам, з одного боку, одержувати доходи від продажу телевізійних прав, а з іншого - більш ефективно просувати видовищні послуги на ринок за рахунок формування позитивного іміджу клубу серед потенційних і реальних їх споживачів. За оцінками керівників футбольних клубів, які брали участь у соціологічному опитуванні, лише кожен п'ятий клуб регулярно співпрацює із засобами масової інформації, оскільки має можливість бути присутнім на телевізійних екранах країни. При цьому рівень співробітництва клубів з представниками медіапростору варто визнати досить низьким.

Характер мікросередовища маркетингу футбольних клубів Лівану багато в чому визначається діяльністю органів управління футболом країни. На національному рівні управління здійснює Федерація футболу Лівану (LFA), яка є членом Національного олімпійського комітету Лівану й працює під його керівництвом. Вона заснована у 1933 р., є членом FIFA й Азіатської футбольної конфедерації (AFC). LFA керує Прем'єр-лігою найвищим футбольним дивізіоном країни [6].

Аналіз діяльності LFA свідчить про те, що на сьогодні вона ще не в змозі істотно впливати на впровадження систем управління маркетингом футбольних клубів Прем’єр-ліги. Фахівці, які брали участь в опитуванні, не мають узгодженості в думках про роль Федерації в цьому питанні: 36,3% 3 них заявили, що вона не надає жодної допомоги маркетологам футбольних клубів, 33,3 \% висловили переконаність в тому, що LFA надає клубам методичну допомогу, 11,4 \% стверджували, що LFA надає допомогу в організації телевізійних трансля- 


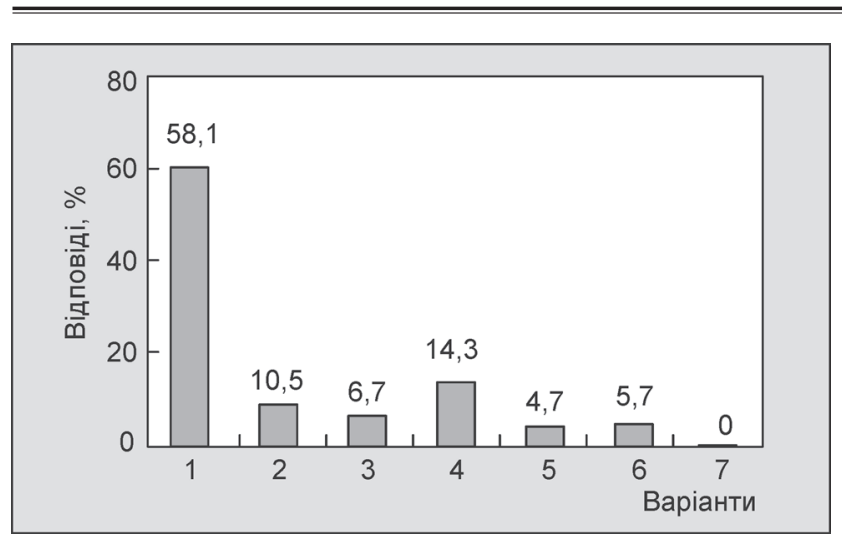

Рисунок 2 - Оцінка факторів, що перешкоджають застосуванню маркетингу футбольними клубами Лівану:

1 - Відсутність фахівців

2 - Небажання керівників клубів займатися маркетингом

3 - Недооцінка ролі маркетингу у розвитку клубів

4 - Відсутність необхідних соціально-економічних умов для розвитку футболу

5 - Відсутність компаній, які бажають стати спонсорами клубів

6 - Складна політична ситуація в країні

7 - Інші причини

цій ігор клубів, а 14,3 \% упевнені в тому, що вона надає клубам допомогу в залученні спонсорів.

Головними факторами мікросередовища, які перешкоджають впровадженню маркетингу у систему управління футбольними клубами Лівану, сьогодні експерти називають відсутність кваліфікованих фахівців, а також небажання керівників клубів займатися цієї діяльністю (рис. 2).

Як бачимо, серед факторів негативної дії найбільша питома вага $(75,3$ \%) належить тим, які мають суб'єктивний характер, тобто обумовлюються низькою мотивацією керівників клубів активно впливати на організаційне та кадрове забезпечення впровадження маркетингу у практику управління клубами.

Висновки. Аналіз ситуації у ліванському футболі свідчить про незадовільний стан організаційноуправлінських основ застосування маркетингу футбольними клубами. Вирішення проблеми потребує певних зусиль з боку LFA та Прем'єр-ліги 3 метою цілеспрямованої роботи 3 керівниками клубів у формуванні професійного кадрового забезпечення управління маркетинговою діяльністю, а також їх активної участі у визначенні та реалізації стратегій клубного маркетингу.

Перспективи подальших досліджень передбачають доцільне спрямування поглибленого вивчення зовнішнього та внутрішнього середовища розвитку ліванського футболу та наукове обгрунтування особливостей формування системи управління маркетингом футбольних клубів.

Конфлікт інтересів. Автори запевняють, що відсутній будь-який конфлікт інтересів.

\section{Література}

1. Болховер Д. Менеджер на 90 минут. - Днепропетровск: Баланс-Клуб; 2003. 256 с.

2. Імас $€ B$, Мічуда ЮП, Ярмолюк ОВ. Маркетинг у спорті: теорія та практика. Київ: Олімп. л-ра; 2016. 272 с.

3. Котлер Ф. Маркетинг менеджмент. - Питер; 2014. 800 с.

4. Ліван: Населення. - Режим доступу: https://uk.wikipedia.org/wiki.

5. Степанова ОН. Маркетинг в сфере физической культуры и спорта: монография. - 3-е изд. - Москва: Сов. спорт; 2007. 256 с.

6. Футбольная фредерация Ливана. - Режим доступу до дж. http://www.greatfootball.com.ua/lebanon/lib-ff.php.

7. Mullin B. Sport Marketing. Third Edition / B. Mullin, S. Hardy, W. Sutton. - Champaign III., Human Kinetics Publ., 2007. 540 p.

\section{Literature}

1. Bolhover D. Manager for 90 minutes. - Dnepropetrovsk: Balans-Klub; 2003. 256 p.

2. Imas leV, Michuda YP, larmoliuk OV. Marketing in sport: theory and practice. Kyiv: Olimpiiska literatura; 2016.272 p.

3. Kotler F. Marketing management. - Piter; 2014. 800 p.

4. Lebanon: Population. - Access mode: https://uk.wikipedia.org/wiki.

5. Stepanova ON. Marketing in physical culture and sport: monograph. - $3^{\text {rd }}$ ed. - Moscow: Sov. sport; 2007.256 p.

6. Football federation of Lebanon - Access mode http://www.greatfootball.com.ua/lebanon/lib-ff.php.

7. Mullin B. Sport Marketing. Third Edition / B. Mullin, S. Hardy, W. Sutton. - Champaign III., Human Kinetics Publ., 2007. 540 p.

Надійшла 20.08.2018

Інформація про авторів

Мічуда Юрій Петрович

https:orcid.org/0000-0002-0259-176X

ypmichuda2017@gmail.com

Мустафра Ісмаїл

mostafa-1966@hotmail.com

Національний університет фрізичного виховання і спорту України, 03150, Київ, вул. Фізкультури, 1.
Information about the authors

Michuda Yuriy https://orcid.org/0000-0002-0259-176X ypmichuda2017@gmail.com

Mostafa Ismail mostafa-1966@hotmail.com

National University of Ukraine on Physical Education and Sport, 03150, Kyiv, Fizkul'tury st 